\title{
Structure and Properties of Brazilian Peat: Analysis by Spectroscopy and Microscopy
}

\author{
Luciane P. C. Romão, ${ }^{*, a}$ Jamie R. Lead, ${ }^{b}$ Julio C. Rocha, ${ }^{c}$ Luciana Camargo de Oliveira, ${ }^{c}$ \\ André H. Rosa, ${ }^{d}$ André G. R. Mendonça ${ }^{c}$ and Adauto de Souza Ribeiro ${ }^{e}$
}

\author{
${ }^{a}$ Departamento de Química, Universidade Federal de Sergipe, 49100-000 São Cristovão-SE, Brazil
}

${ }^{b}$ Division of Environmental Health and Risk Management, School of Geography, Earth and Environmental Sciences, University of Birmingham, B15 2TT, Birmingham, United Kingdom

${ }^{c}$ Instituto de Química, Universidade Estadual Paulista, 14800-900 Araraquara-SP, Brazil

${ }^{d}$ Departamento de Engenharia Ambiental, Universidade Estadual Paulista,18087-180 Sorocaba-SP, Brazil

${ }^{e}$ Departamento de Biologia, Universidade Federal de Sergipe, 49100-000 São Cristovão-SE, Brazil

\begin{abstract}
Amostras de turfa (SAO e ITA) coletadas no Estado de Sergipe, Brasil, foram caracterizadas por diferentes técnicas: análise térmica e elementar, infravermelho, espectroscopia de ressonância magnética nuclear de ${ }^{13} \mathrm{C}(\mathrm{NMR})$, microscopia eletrônica de varredura (SEM), microscopia eletrônica de varredura ambiental (ESEM), difratometria de raios X (XRD) e comparadas com outras amostras de turfa (SAP) coletadas no Estado de São Paulo, Brasil. As razões mais baixas $\mathrm{O} / \mathrm{C}, \mathrm{E}_{4} / \mathrm{E}_{6}$ e as curvas de análise térmica diferencial (DTA) da amostra de Santo Amaro (SAO) indicaram que esta possui o mais alto grau de decomposição. Resultados da espectroscopia na região do infravermelho mostraram que as amostras de Itabaiana (ITA) e São Paulo (SAP) apresentam pico predominante a $1086 \mathrm{~cm}^{-1}$ atribuídos a presença de Si-O diferente da amostra de Santo Amaro (SAO). Esta mostrou dois picos intensos a $2920 \mathrm{~cm}^{-1}$ e $2850 \mathrm{~cm}^{-1}$ corroborando com dados de RMN ${ }^{13} \mathrm{C}$ e análise termogravimétrica em que houve maior abundância dos grupos C-alquila. A difratometria de raios $\mathrm{X}$ (XRD) da amostra de SAO apresentou características de material amorfo. Entretanto, as amostras de SAP e ITA revelam maior presença de quartzo mineral. A microscopia eletrônica de varredura (SEM) e a microscopia eletrônica de varredura ambiental (ESEM) mostraram que a superfície das amostras de turfa possui grânulos porosos de matéria orgânica. As amostras de turfa de ITA e SAP são semelhantes enquanto a de SAO possui alto teor de matéria orgânica. Apenas a amostra de SAO apresenta características de turfa. Os resultados deste estudo mostraram que as amostras são muito diferentes devido aos teores variáveis de material orgânico e inorgânico.
\end{abstract}

Peat was taken from the Sergipe State, Brazil and characterized by several techniques: elemental and thermal analyses; Fourier infrared (FTIR) and solid state ${ }^{13} \mathrm{C}$ nuclear magnetic resonance (NMR) spectroscopies; scanning electron microscopy (SEM), environmental scanning electron microscopy (ESEM) and X-ray diffractometry (XRD). Also, the Sergipe State peat samples were compared with other peat sample from later from Sao Paulo State, Brazil. The lowest $\mathrm{O} / \mathrm{C}$ and $\mathrm{E}_{4} / \mathrm{E}_{6}$ ratios and differential thermal analysis (DTA) curves of the Santo Amaro (SAO) sample indicated that this sample had the highest degree of decomposition. FTIR results showed that Itabaiana (ITA) and São Paulo (SAP) samples presented more prominent peak at $1086 \mathrm{~cm}^{-1}$ attributed the presence of Si-O than SAO sample spectra. The SAO sample showed two more intense peaks at $2920 \mathrm{~cm}^{-1}$ and 2850 $\mathrm{cm}^{-1}$. These results were corroborated by ${ }^{13} \mathrm{C}$ NMR and thermal gravimetric (TG) where the relative abundance of the alkyl-C groups was greater in the SAO sample. The X-ray diffractometry (XRD) of SAO sample is characteristic of amorphous matter however, the SAP and ITA samples revealed the large presence of quartz mineral. The scanning electron microscopy (SEM) and environmental scanning electron microscopy (ESEM) showed that the surface of peat samples have porous granules of organic material. The ITA and SAP peat samples are alike while SAO peat sample is richer in organic material. Only the SAO sample has truthful characteristics of peat. The results of this study showed that the samples are very different due to variable inorganic and organic material contents.

Keywords: peat structure and properties,spectroscopy and microscopy characterization, scanning electron microscopy, environmental scanning electron microscopy

\footnotetext{
*e-mail: luciane@ufs.br
} 


\section{Introduction}

Peat is formed primarily from inhibited decomposition of various plant materials in the waterlogged environment of marshes, bogs and swamps., ${ }^{1,2}$ Natural peats, continuously formed by complex humification processes from plant residues, are important reservoirs of refractory organic carbon in aquatic environments. Due to their high content of humic substances, natural peats exhibit favourable chemical-physical properties enabling their useful application in various technical areas, for instance wastewater treatment, pollution monitoring, fuel production, in soil fertilizing, as well as, in veterinary and human medicine. Previous work has established that the ability of humic substances to bind heavy metal ions can be attributed to their high content of oxygencontaining functional groups, including carboxyl, phenol, hydroxyl, enol and carbonyl structures of various types. ${ }^{3-}$ ${ }^{6}$ Humic substances are classified according to their solubility in water as humic acids, fulvic acids and humin. The last is the fraction with the highest molecular weight and highest carbon content of the three humic fractions. In addition, humin is extremely porous and, as a consequence, the surface area is very large. The availability of pores and internal surface are useful in the adsorption process. ${ }^{7}$ Clay mineral constituents, such as kaolinite and montmorillonite, are also found in peat samples, and contribute to the high adsorption capacity attributed to net negative charge on the structure of silicate minerals. This negative charge is neutralized by the adsorption of positively charged species, such as heavy metals. ${ }^{5}$ Thus, organic-rich and mineral-rich peat samples can be different in their binding capacity for metals (e.g. chromium).

The need for controlling heavy metals emissions into the environment is even more pronounced due to exponentially increasing human populations, which can be exposed once the metallic species enter the ecosystem. Nowadays, under the public and media pressure, governments introduce and progressively enforce stricter regulations with regard to metal discharges particularly for industrial operations. ${ }^{8}$

For this reason, increased attention is being focused on effective and inexpensive technologies capable of treating large quantities of wastewater. The advantage of biosorption lies in using biomass raw materials (e.g. peat) which are easily available and can be selective particularly to heavy metals. The last aspect is important and may be achieved by manipulating the properties or characteristics of a biosorbent. Besides, subsequent desorption for recovery/reuse of metals as well as regeneration/reuse of the biosorbent are crucially important for keeping the process costs down and to prevent creation of secondary problems with metal-bearing sludges which are extremely difficult for disposal. These concepts are considered in principles of green chemistry which underpin this kind of research. $^{8-10}$

Due to their extreme heterogeneity and natural variety, chemical attributes of peat can vary widely among different peat deposits, and the characterization of isolated peat samples and their manifold effects is still a challenging task in environmental analytical chemistry requiring efficient combinations of powerful chemical and spectroscopic methodologies.

In the present paper we have applied a new multimethod approach, consisting of elemental and thermal analyses, Fourier transform infrared (FTIR), solid state ${ }^{13} \mathrm{C}$ nuclear magnetic resonance $\left({ }^{13} \mathrm{C}\right.$ NMR $)$, scanning electron microscopy (SEM), environmental scanning electron microscopy (ESEM) and X-ray diffractometry (XRD), to study the structure and properties of typical Brazilian peat samples. Such a multimethod concept is an important prerequisite for a reliable assessment of beneficial peat effects in the environment. Chromium sorption onto different peat fractions will be reported in a forthcoming paper.

\section{Experimental}

\section{Peat samples}

Three peat samples have been collected from two different regions of Sergipe State, Brazil, Itabaiana (ITA) and Santo Amaro (SAO), and one from Sao Paulo (SAP) State, Brazil. The raw peat was dried in an oven at $100^{\circ} \mathrm{C}$ for $24 \mathrm{~h}$ and then sieved though a 9 mesh sieve and analysed without further treatment.

Dry ash, $H / C, O / C$ and $E_{4} / E_{6}$

A Perkin Elmer 1110 elemental analyzer determined the elemental composition of peat samples. The proportion of dry ash was obtained after ignition at $750^{\circ} \mathrm{C}$ for $4 \mathrm{~h} .{ }^{11}$ $\mathrm{E}_{4} / \mathrm{E}_{6}$ ratios were determined by dissolving $2.0 \mathrm{mg}$ of peat in $10 \mathrm{~mL}$ of $0.05 \mathrm{~mol} \mathrm{~L}^{-1} \mathrm{NaHCO}_{3}$ solution $(\mathrm{pH} 9.0$ in all (ases) ${ }^{12}$ and by measuring optical densities at 465 and $665 \mathrm{~nm}$ on a Hitachi U 2000 spectrophotometer.

\section{Infrared spectroscopy}

The peat samples $(0.035 \mathrm{~g}$ each) were mixed with 0.35 $\mathrm{g}$ of $\mathrm{KBr}$ (spectroscopic grade) at the biomass $/ \mathrm{KBr}$ ratio 
1:10. The mixtures were then pressed into pellets for FTIR analysis. The spectra were recorded on a Nicolet $730 \mathrm{SX}$ FT spectrometer on a spectral range of $4000-400 \mathrm{~cm}^{-1}$.

\section{Solid state ${ }^{13} \mathrm{C}$ NMR spectroscopy}

The samples (120 a $150 \mathrm{mg}$ ) were crushed and ground into powder prior to analysis. Spectra were recorded on a Varian INOVA-300 spectrometer working at $75.4 \mathrm{MHz}\left({ }^{13} \mathrm{C}\right)$. ${ }^{13} \mathrm{C}$ spectra were recorded with a spinning frequency of 3000 $\mathrm{Hz}$, a $90^{\circ}$ pulse and acquisition time of $6 \mathrm{~s}$. The reference at 0 ppm was $\mathrm{SiMe}_{4}$. Chemical shifts were assigned according to Swift (1996): ${ }^{13}$ alkyl-C from 0 to 65 ppm; O-alkyl-C from 65 to $110 \mathrm{ppm}$; aromatic-C from 110 to $140 \mathrm{ppm}$; phenolic$\mathrm{C}$ from 140 to $160 \mathrm{ppm}$; carboxylic-C from 160 to $190 \mathrm{ppm}$ and carbonyl-C from 190 to $220 \mathrm{ppm}$.

\section{Thermal analyses}

For DTA and (TG) analysis, about $8 \mathrm{mg}$ of peat samples were ground with a mortar and pestle and sieved through a 70 mesh sieve to homogenize them. After the samples were heated continuously from 40 to $1000^{\circ} \mathrm{C}$ at a heating rate of $10{ }^{\circ} \mathrm{C} \mathrm{min}-1$ in an atmosphere of synthetic air $\left(99.999 \%, 20 \% \mathrm{O}_{2}\right.$ and $\left.80 \% \mathrm{~N}_{2}\right)(100 \mathrm{~mL}$ $\min ^{-1}$ ) and in an alumina crucible. In the differential thermal analysis the temperature difference between sample and inert reference material ( $\alpha$-alumina) was measured. DTA and TG curves were recorded simultaneously using TA Instruments SDT-2960. The thermal analyses were done in duplicate with a standard deviation of $0.1 \%$.

\section{$X$-ray diffractometer}

Detailed mineralogical studies of peat samples were carried out using a X-ray diffraction (SIEMENS D-5000) with $\mathrm{CuK} \alpha$, step time $1 \mathrm{~s}$, step size $0.05 \mathrm{dg}$ and wave length $1.54 \AA$.

\section{Scanning Electron Microscopy}

Measurements were performed using a JSM T330A SEM in ultra high vaccum. Peat samples were placed onto clean electron microscopy support stubs, coated with gold in an Emscope SC 500 sputter coater.

\section{Environmental Scanning Electron Microscopy}

All measurements were carried out in a FEI XL-30 FEG-ESEM in wet mode, fitted with a water cooled Peltier stage fitted. All images were obtained at $2{ }^{\circ} \mathrm{C}$ and the pressure altered below 10 Torr to maintain humidities between 25 and $100 \%$. Samples were imaged with a gaseous secondary electron detector using $10 \mathrm{kV}$ electron beam and using $\mathrm{H}_{2} \mathrm{O}$ for the vapour skirt.

\section{Results and Discussion}

The elemental analyses, elemental ratios, dry ash and ratios $\mathrm{E}_{4} / \mathrm{E}_{6}$ are listed in Table 1. The decomposition of organic material present in the peat samples tends to lead to the formation of phenolic structures derived from lignin. It is harder for these structures to suffer degradation compared with sugars and proteins. ${ }^{11}$ The H/C and O/C ratios are indicators for the percentage saturation of the $\mathrm{C}$ atoms within the organic molecule and of the carbohydrate content respectively. Lower $\mathrm{H} / \mathrm{C}$ ratios indicate higher aromaticity in the samples. There are similarities between the $\mathrm{H} / \mathrm{C}$ ratios of the samples and the values in the literature, indicating considerable aromaticity. ${ }^{14}$ The lowest $\mathrm{O} / \mathrm{C}$ ratio of the $\mathrm{SAO}$ sample indicates the lowest carbohydrate level and/or the highest organic content of that peat sample. ${ }^{15}$

The measure of $E_{4} / E_{6}$ ratio is a simple spectroscopic property which has been used to characterize the progress of decomposition. ${ }^{12}$ This ratio has been correlated negatively with increasing content of condensed aromatic structures. ${ }^{16}$

All together, the results indicate that the SAO peat is highly humified and rich in organics, while the other two peats contain less organic matter of different composition.

Figure 1 shows the infrared spectra of the different peat samples. The spectra characteristics are broad bands typical of natural organic matter due to superposition of individual absorptions bands. ${ }^{17}$ The most consistent features of these spectra are: a) a broad band around 3400 $\mathrm{cm}^{-1}$ due to $\mathrm{O}-\mathrm{H}$ stretching of various groups like phenols

Table 1. Location, elemental ratios $(\%)$, ash content $(\%)$ and $\mathrm{E}_{4} / \mathrm{E}_{6}$ ratios of peat samples from different Brazilian regions

\begin{tabular}{|c|c|c|c|c|c|c|c|c|c|}
\hline Label & Location & $\mathrm{C}$ & $\mathrm{H}$ & $\mathrm{N}$ & $\mathrm{O}^{* *}$ & Dry ash & $\mathrm{H} / \mathrm{C}$ & $\mathrm{O} / \mathrm{C}$ & $\mathrm{E}_{4} / \mathrm{E}_{6}$ \\
\hline SAO & Peat from Santo Amaro/Sergipe & 53.1 & 6.0 & $\mathrm{Nd}^{*}$ & 31.5 & 9.4 & 1.3 & 0.4 & 1.6 \\
\hline ITA & Peat from Santo Amaro/Sergipe & 5.1 & 0.5 & $\mathrm{Nd}^{*}$ & 6.6 & 87.8 & 1.1 & 1.0 & 1.7 \\
\hline SAP & Peat from Ribeirao Preto/Sao Paulo & 6.2 & 1.0 & 0.2 & 11.7 & 80.9 & 1.88 & 1.4 & 2.0 \\
\hline
\end{tabular}

* Not determined; ${ }^{* *}$ By difference 
and alcohol; b) two peaks at $2920 \mathrm{~cm}^{-1}$ and $2850 \mathrm{~cm}^{-1}$ due to $\mathrm{C}-\mathrm{H}$ stretching; c) a peak at $1626 \mathrm{~cm}^{-1}$ assigned to aromatic $\mathrm{C}=\mathrm{C}$ stretching; d) a strong peak at $1086 \mathrm{~cm}^{-1}$ due to Si-O stretching. ${ }^{17}$

The ITA and SAP samples presented more prominent peak at $1086 \mathrm{~cm}^{-1}$ than SAO sample spectra, indicating more $\mathrm{Si}-\mathrm{O}$ groups present. In addition the $\mathrm{SAO}$ spectra contained two more prominent peaks at $2920 \mathrm{~cm}^{-1}$ and $2850 \mathrm{~cm}^{-1}$. Most likely, these peaks are due to stretching $\mathrm{C}-\mathrm{H}$ due to $\mathrm{C}$ alkyl and are much less pronounced in the less organic ITA and SAP samples.

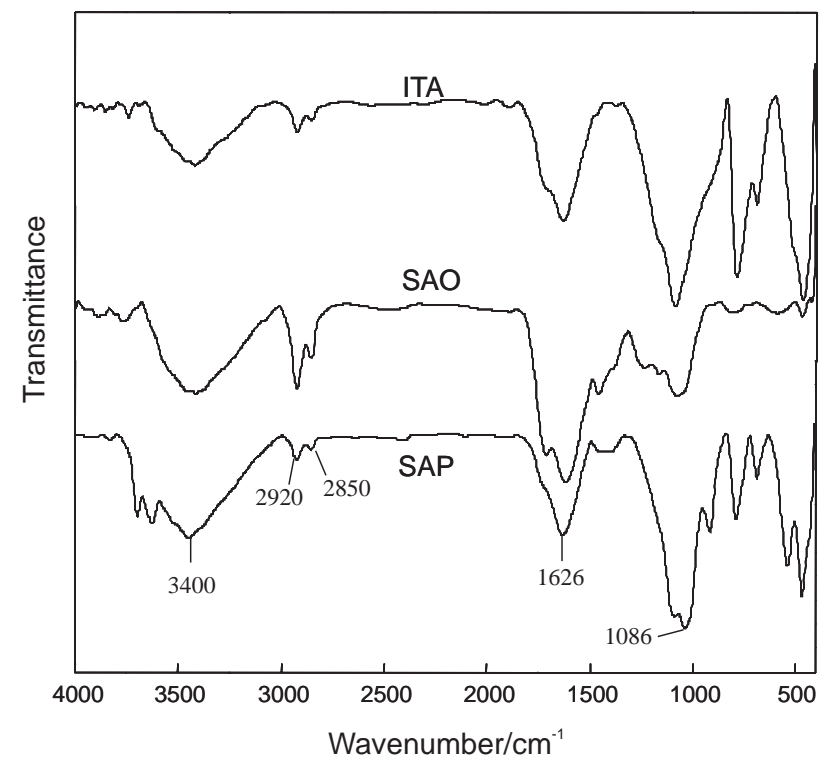

Figure 1. IR spectrum of the peat samples from different Brazilian regions.

The chemical shifts assignments of ${ }^{13} \mathrm{C}$-NMR spectra and their relative abundance obtained are given in Table 2.

All three peat samples are highly aromaticity and slow similarities with the literature data for coal humic acid (HA). ${ }^{18}$ In addition, Gondar et al. ${ }^{19}$ has shown that alkyl$\mathrm{C}$ were the dominant $\mathrm{C}$ components in peat humic acids (HA) and fulvic acids (FA). In particular, the FA contains more alkyl-C and carboxylic carbon but less O-alkyl-C and aromatic-C than the corresponding HA. The abundance of alkyl-C groups was greater in the SAO sample than others and this is consistent with the results from the FTIR analysis. The results of ITA and SAP samples showed similarities each other and were different when compared with SAO sample.
The DTA curves are given in Figure. 2 and indicate exothermic reactions in all samples, due to the oxidation of organic matter. In a TG analysis the mass of a sample in a controlled atmosphere is recorded continously as a function of temperature or time as the temperature of the sample is increased. The SAO sample shows an endothermic peak near to $100{ }^{\circ} \mathrm{C}$ accompanied by weight loss of $5 \%$ of dehydration of sample (Figure 3). This sample shows higher exothermic effect between $300-400{ }^{\circ} \mathrm{C}$ and $500{ }^{\circ} \mathrm{C}$. This indicated that SAO has higher organic matter and these results are corroborated with the dry ash, $\mathrm{O} / \mathrm{C}$ and $\mathrm{E}_{4} / \mathrm{E}_{6}$ ratios and FTIR. According to Leinweber and Schulten, ${ }^{20}$ the exothermic effect in this temperature range can be more pronounced with greater peat formation time.

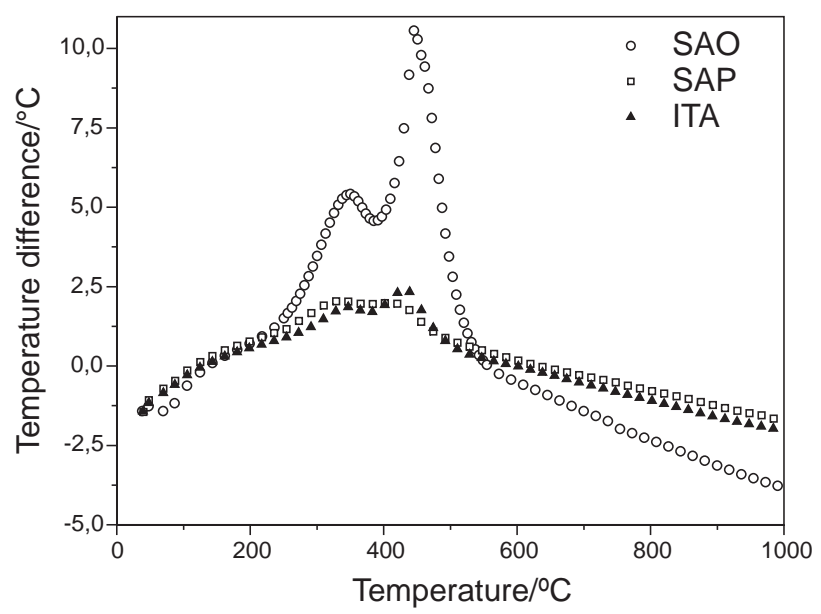

Figure 2. DTA curves of the peat samples from different Brazilian regions.

The weight loss curves in Figure 3 shows that the decomposition of soil organic matter (SOM) increases at $300{ }^{\circ} \mathrm{C}$ and is largely completed before $600{ }^{\circ} \mathrm{C}$. The weight loss of the peat samples in different range of temperature are shown in the Table 3. In that range of temperature the higher variation of weight occured to the SAO sample (9.93\%), while in the others the variation was almost $2 \%$ probably, due to greater organic matter content of that sample. Tikhova et al. ${ }^{21}$ have shown that exothermic reaction in the range of $280-320^{\circ} \mathrm{C}$ corresponds to the thermal decomposition of aliphatic chain and carboxyl groups attached to it. This indicates higher presence of alkyl groups in that SAO sample and this is corroborated with the results from ${ }^{13} \mathrm{C}$ NMR.

Table 2. Chemical assignments (\%) of ${ }^{13} \mathrm{C}$ NMR spectra of peat samples from different Brazilian regions

\begin{tabular}{lcccccc}
\hline Samples & \multicolumn{5}{c}{ Assigments } \\
\hline & Alkyl-C & O-alkyl-C & Aromatic-C & Phenolic-C & Carboxylic-C & Carbonyl-C \\
SAO & 41.4 & 11.9 & 24.1 & 8.9 & 9.3 & 4.5 \\
ITA & 19.7 & 18.1 & 39.3 & 6.7 & 8.1 & 8.0 \\
SAP & 17.6 & 19.5 & 36.0 & 6.9 & 11.4 & 8.5 \\
\hline
\end{tabular}




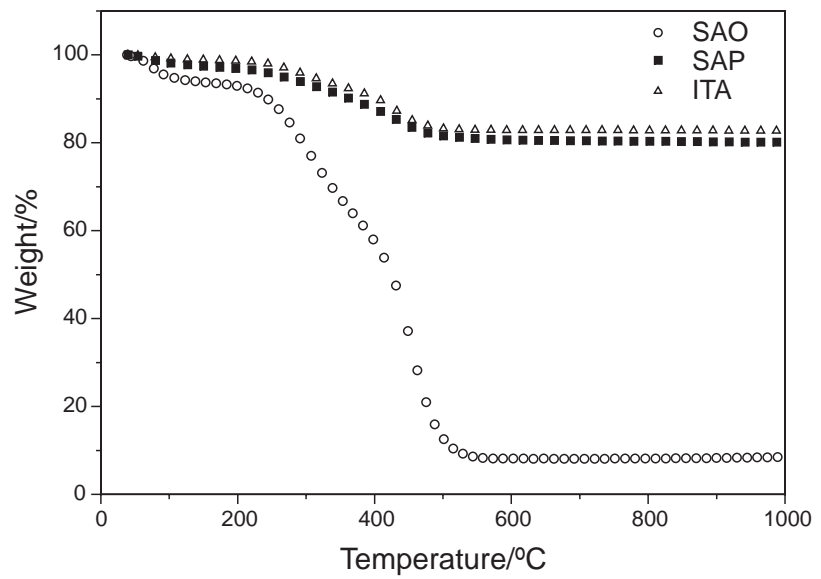

Figure 3. TG curves of the peat samples from different Brazilian regions

Detailed examination of the mineralogy of the peat samples using XRD is shown in the Figure 4. The XRD of SAO sample (Figure 4a1) is characteristic of amorphous matter with a hump, between $18^{\circ}$ and $32^{\circ}$. Bozkurt et al. ${ }^{15}$ analyzing the processes involved in peat formation, recognized an anaerobic thick structural layer, which is formed of residual material from the original plant structure, decay products and new substances produced mainly by bacteria. At this level peat would be amorphous and highly humified. However, only the XRD of dry ash or residue of that sample revealed

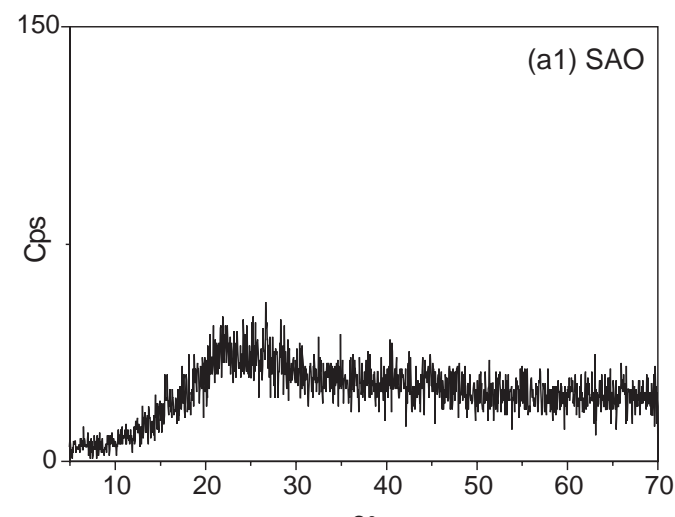

(a1) SAO $2 \theta$

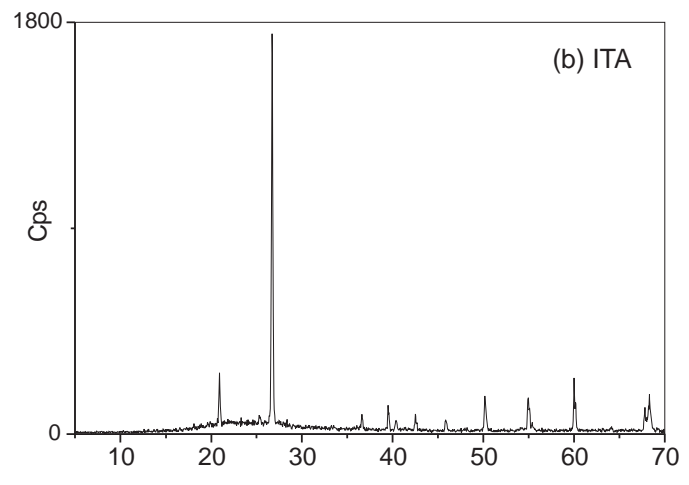

(b) ITA

$2 \theta$
Table 3. Weight loss of the peat samples in different ranges of temperature

\begin{tabular}{lccc}
\hline Temperature range $/{ }^{\circ} \mathrm{C}$ & \multicolumn{3}{c}{ Weight loss/ \% } \\
\cline { 2 - 4 } & SAO & ITA & SAP \\
\hline $0-100$ & 5.0 & 0.9 & 1.8 \\
$100-200$ & 2.0 & 0.1 & 1.5 \\
$200-300$ & 14.0 & 2.1 & 3.2 \\
$300-400$ & 21.3 & 2.0 & 5.7 \\
$400-500$ & 43.8 & 6.3 & 6.3 \\
$500-600$ & 4.5 & - & 0.6 \\
$600-1000$ & - & - & - \\
\hline
\end{tabular}

mineral characteristics with presence of quartz mineral and some clay material. These materials were recovered by the organic matter of peat (Figure 4a2). The XRD of SAP and ITA samples revealed the large presence of quartz mineral (Figure $4 \mathrm{~b}$ and $4 \mathrm{c}$ ). This feature is more related with mineral characteristic of those samples, which were observed in the FTIR spectra and the higher results of dry ash in that samples.

SEM and ESEM are shown in Figures 5 and 6, respectively. There are similarities between the two techniques, SEM and ESEM of the samples have shown that the surface of peat samples have porous granules of organic material. Therefore, there are differences between them. SEM images are more densely packed due to drying process and an ultra high vacuum (Figure 5). ESEM is a

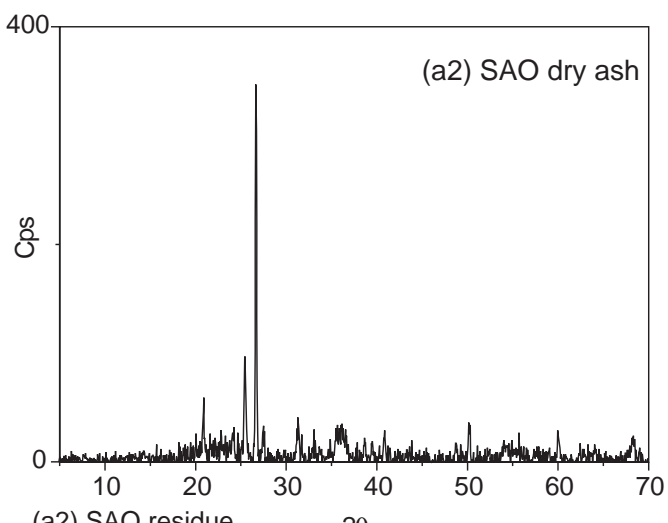

(a2) SAO residue $\quad 2 \theta$

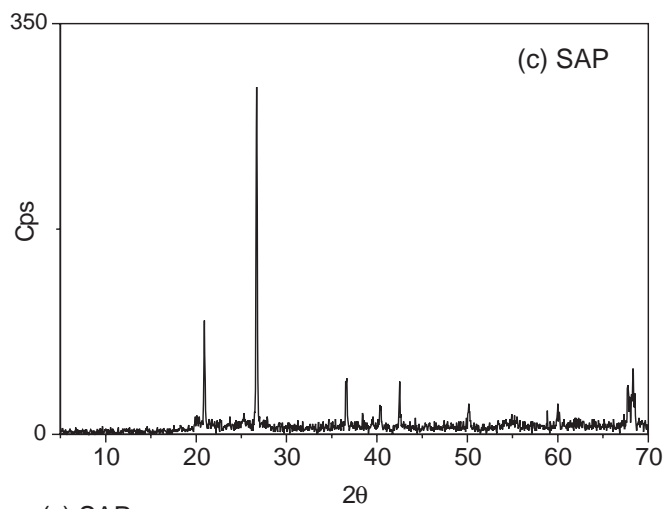

(c) SAP

Figure 4. X-ray diffractometer of peat samples. 
new technique capable of imaging micron and submicron particles and can image wet samples and cycle between wet and dry states. ${ }^{22,23}$ The use of high humidity and low vacuum preserve the structure of material and give more realistic results. Typical aggregate structures of natural organic matter have been observed in SAO sample. Analysis of ITA and SAP samples yielded the results regarding those samples rich in mineral components (Figure 6). These results are corroborated with the dry ash, FTIR, DTA, TG and XRD.

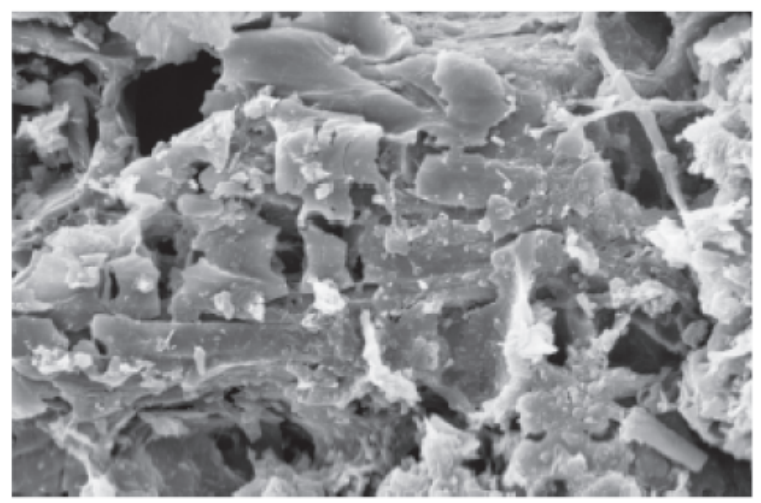

(a) SAO sample

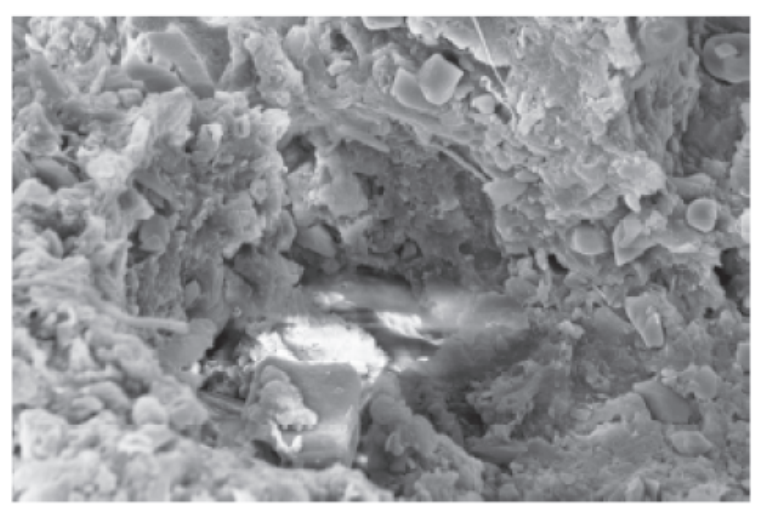

(b) ITA sample

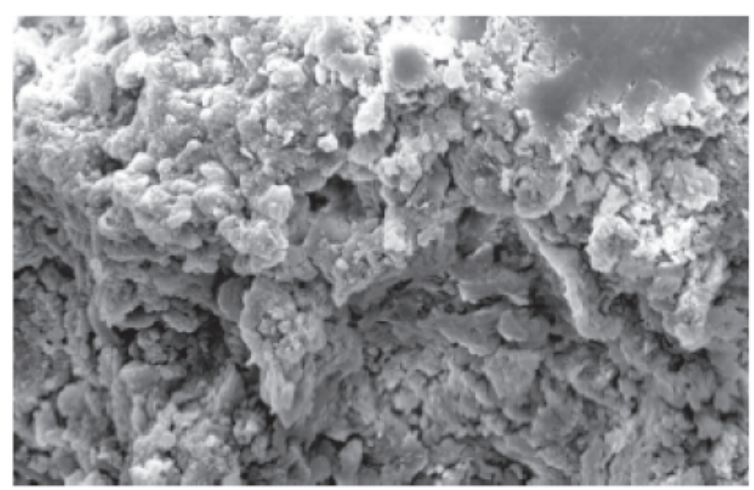

(c) SAP sample

Figure 5. Scanning electron microscopy of peat samples.

\section{Conclusions}

The results of this study using XRD, SEM, ESEM, thermal and elemental analyses showed that the samples are very different due to variable inorganic and organic material contents. The XRD analysis showed that only the SAO sample possessed true characteristics of peat. All three peat samples showed high aromaticity but ${ }^{13} \mathrm{C}$ NMR and FTIR spectroscopies and thermal analysis showed that the abundance of alkyl-C groups was greater

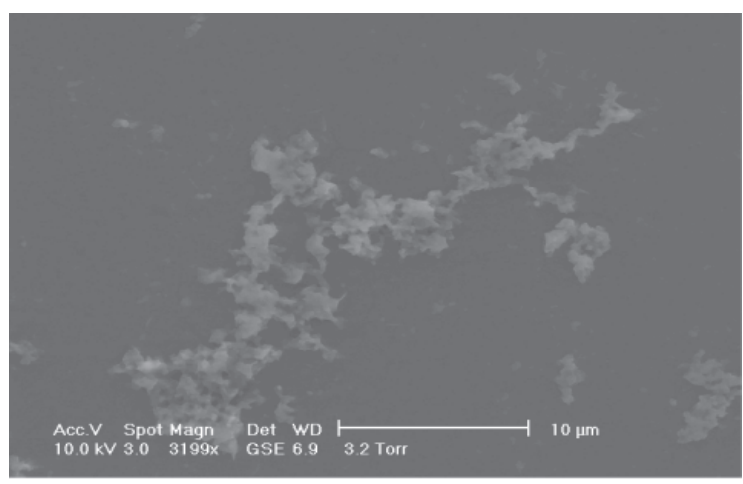

(a) SAO sample

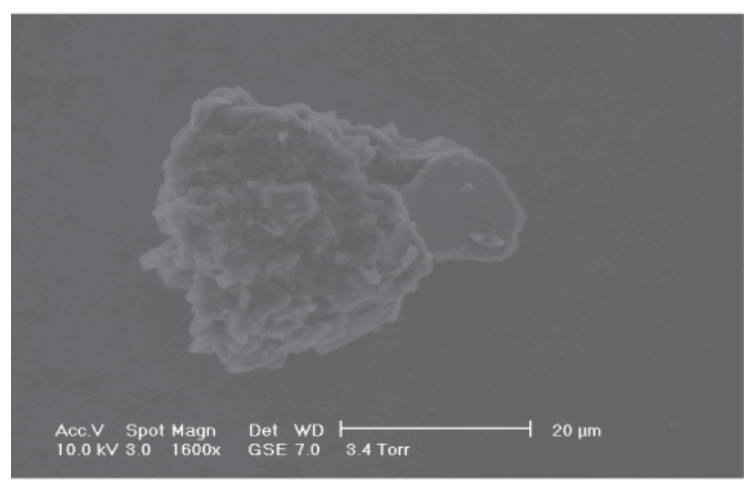

(b) ITA sample

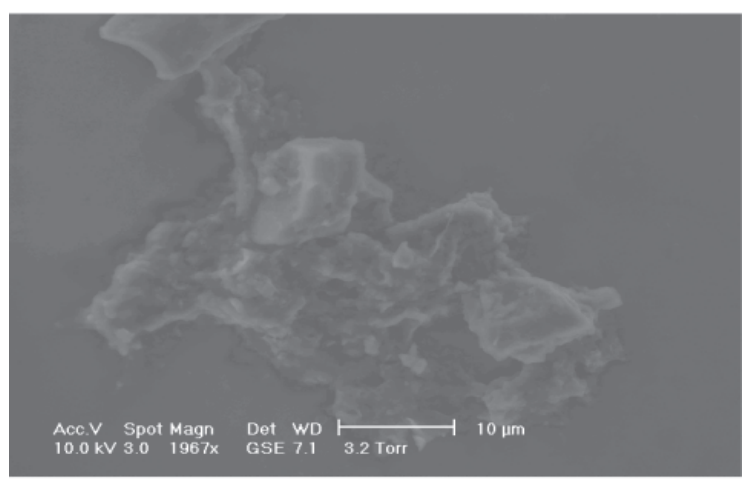

c) SAP sample

Figure 6. Environmental scanning electron microscopy of peat samples. 
in the SAO sample than in others. The presence of these groups is likely to influence metal binding capacity; therefore the capabilities of peat sorbent in technological processes should be investigated in column experiments with manipulation and alteration of their physico-chemical properties. The complex relationship of sorption efficiency with organic and mineral contents of peat samples, which ultimately govern their environmental and economic potentials, can only be studied in detail by a multimethod approach.

\section{Acknowledgments}

This study was supported by the Conselho Nacional de Desenvolvimento Científico e Tecnológico/CNPq (Brazil) (201185/2003-2). The authors wish to thank Dr. Ademir dos Santos and Francisco de Melo Roque for peat samples.

\section{References}

1. Spendding, P.J.; Fuel 1988, 67, 883.

2. Bragg, O.M.; Sci. Total Environ. 2002, 294, 111.

3. Aiken G. R.; Mcknight, D. M.; Wershaw, R.L.; Maccarthy, P.; Humic Substances in Soil, Sediment And Water. John Wiley: New York, 1985.

4. Couillard, D.; Water Res. 1994, 28, 1261.

5. Bailey, S. E.; Olin, T. J.; Bricka, R. M.; Adrian, D. D.; Water Res. 1999, 33, 2469.

6. Brown, P.A.; Gill, S.A.; Allen, S.J.; Water Res. 2000, 34, 3907.

7. De la Rosa, G.; Gardea-Torresdey, J.L.; Peralta-Videa, J.R.; Herrera, I.; Contreras, C.; Bioresou. Technol., 2003, 90, 11.

8. Volesky B.; Hydrometallurgy 2001, 59, 203.
9. Almorin, W. B.; Hayashi, A. M.; Pimentel, P. F.; Silva, M. G. C.; Braz. J. Chem. Eng. 2003, 20, 283.

10. Anastas, P. T; Warner, J. C.; Green Chemistry: Theory and Practice, Oxford University Press: New York, p. 135, 1998.

11. Rocha, J. C.; Rosa, A. H.; Furlan, M.; J. Braz. Chem. Soc. 1998, 9, 51 .

12. Stevenson, F. J.; Humus Chemistry: Genesis, Composition, Reactions, $2^{\text {nd }}$ ed., John Wiley: New York, 1994.

13. Swift, R. S.; In Methods of Soils Analysis, Part III: Chemical Methods, SSSA: Madison, 1996.

14. Araújo, A. B.; Rosa, A. H.; Rocha J. C.; Romão, L. P.; Quim. Nova 2002, 25, 1103.

15. Bozkurt, S.; Lucisano, M.; Moreno, L.; Neretnieks, I.; EarthScience Reviews 2001, 53, 95.

16. Martin-Neto, L.; Roseli, R.; Sposito, G.; Geoderma 1998, 81, 305.

17. Poppi, N. R.; Talamoni, J.; Quim. Nova 1992, 15, 281.

18. Dick, D. P.; Mangrich, A. S.; Menezes, S. M. C.; Pereira, B. F.; J. Braz. Chem. Soc. 2002, 13, 177.

19. Gondar, D.; Lopez, R.; Fiol, S.; Antelo, J. M.; Arce, F.; Geoderma 2005, 126, 367.

20. Leinweber, P.; Schulten, H.R.; Thermochim. Acta 1992, 200, 151.

21. Tikhova, V. D.; Shakirov, M. M.; Fadeeva, V. P.; Dergacheva, M. I.; Russ. J. Appl. Chem. 1998, 71, 1229.

22. Donald, A. M.; He, C.; Royall, C. P.; Sferrazza, M.; Stelmashenko, N. A.; Thiel, B. L.; Colloids Surf., A 2000, 174, 37.

23. Redwood, P. S.; Lead, J. R.; Harrison, R. M.; Stoll, S.; Environ. Sci. Technol. 2005, 39, 1962.

Received: July 17, 2006

Web Release Date: June 19, 2007

FAPESP helped in meeting the publication costs of this article. 